The Book of Fermentology

\title{
Tasting the History of Wine
}

Charles Ludington ${ }^{1}$, Ann-Sophie Barwich ${ }^{2}$

${ }^{1}$ North Carolina State University, ${ }^{2}$ Indiana University Bloomington

NC State University Libraries

Published on: Dec 03, 2021

License: Creative Commons Attribution 4.0 International License (CC-BY 4.0). 
Editors note: This publication contains the video of the talk from the Fermentology webinar series, as well as a lightly edited transcript of the lecture. The transcript has been enriched with media, annotations, and links to other material by the digital publication team in order to amplify and extend the content for a reading experience.

\section{Abstract}

In this short seminar, Charles Ludington, a historian of both wine and cheese, teams up with Ann-Sophie Barwich to describe key aromas that distinguish notable wines and the history of those aromas. In doing so, he will allow listeners to literally savor specific moments in history and, while doing so, understand the chemistry and neuroscience of just what they are experiencing. Ludington is the author of several books, including The Politics of Wine in Britain: A New Cultural History. (2013, paperback 2016), and most recently, Food Fights: How the Past Matters in Contemporary Food Debates, edited with Matthew Booker (2019). He is currently writing a book about the role of Irish wine merchants in the transformation of Bordeaux into a luxury wine during the eighteenth century.

Ann-Sophie Barwich is a cognitive scientist and empirical philosopher. She is Assistant Professor at Indiana University Bloomington at the Department of History and Philosophy of Science and Medicine and the Cognitive Science Program. Her book "Smellosophy: What the Nose Tells the Mind" (Harvard University Press) investigates olfaction as a new model for theories of mind and brain.

\section{Watch the talk}

Visit the web version of this article to view interactive content.

Tasting the History of Wine with Ann-Sophie Barwich and Chad Luddington by Applied Ecology.

\section{Introduction}

Welcome to another edition of Fermentology. This edition is focusing on the work of two researchers: a historian and a cognitive scientist. Together they illustrate everything to do with wine - and address if we have the same taste, and cognitive abilities, and smell abilities as those professional wine tasters, the sommeliers. $\underline{1}$ 


\section{Wine}

It's a real pleasure to focus on one of my favorite subjects, and I know Ann-Sophie is in full agreement with me, and that is wine, which is perhaps the most famous of all fermented products. In doing so, I want to focus on two things:

1. Why I find wine so fascinating (and why I think you will agree with me that it is very fascinating)

2. What wine tasters do

\section{Bordeaux Wine}

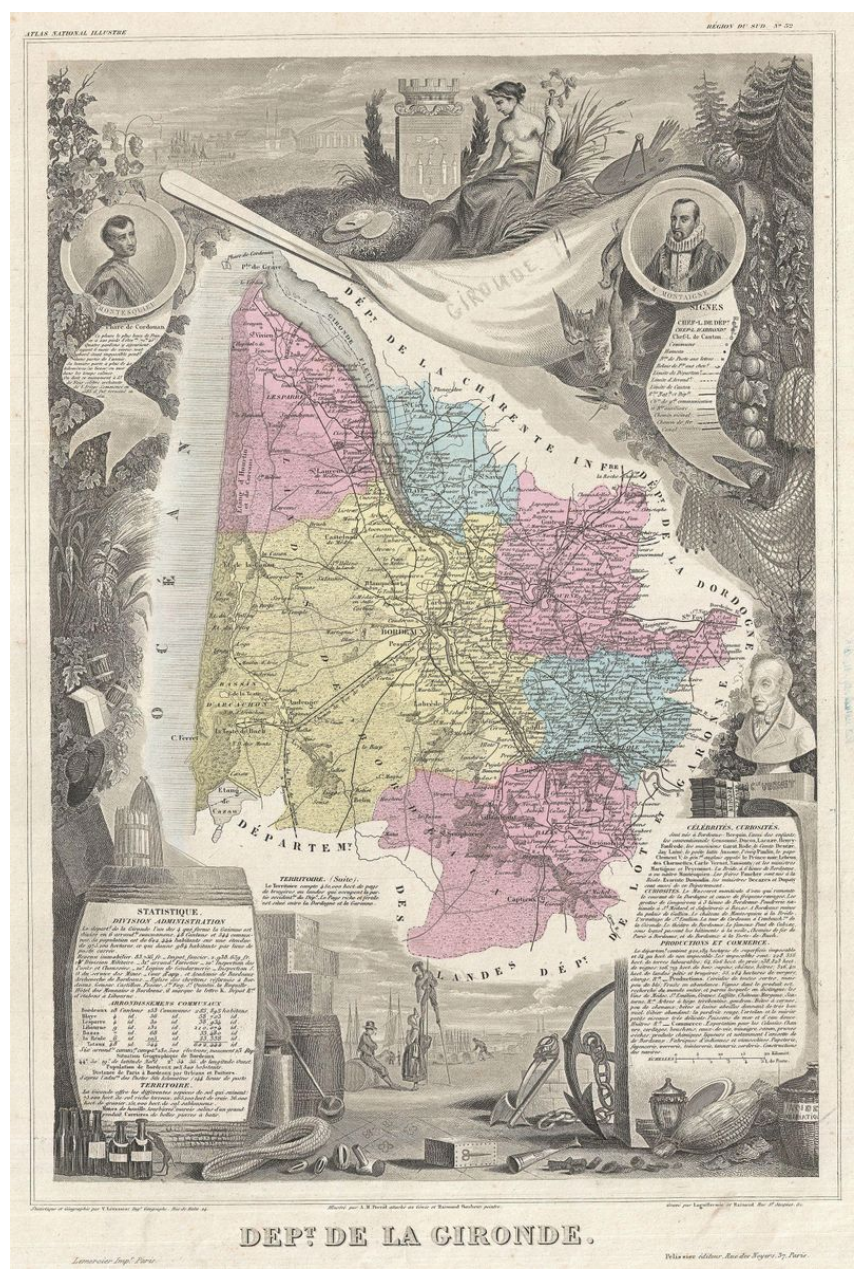

1861 Levasseur Map of the Department de la Gironde (Bordeaux Wine Region). by Victor Jules Levasseur (public domain)
I want to focus particularly on Bordeaux wine. $\underline{2}$ That's perhaps the area I know best. Not only in my studies, I've lived there for a while. And indeed, I enjoy drinking Bordeaux wine - I suspect many of you do too. Bordeaux is also famous even if you don't know why it's famous. You probably know Cabernet Sauvignon and Merlot grapes, and Bordeaux is the home of those two grapes. $\underline{3}$

One of the questions I want to begin with is: How did Bordeaux become such a famous winemaking region? After all, wine is made all over Europe, especially in the southern climates. It's made in Central Asia, where grapes are in the Caucasus. It's of course made in Australia, and South Africa, and South America, in North America, and California, in particular.

But, why did Bordeaux become so famous? 
The first reason is because Bordeaux has long been a wine that was made for export markets -and this is because in 1152, Eleanor of Aquitaine married King Henry II of England. With this marriage, she brought with her, in her impressive dowry, the entire territory of what is now South West France, including the city of Bordeaux, which is about 75 kilometers down the river from the Atlantic Ocean. Making it a port city that is protected by the river.

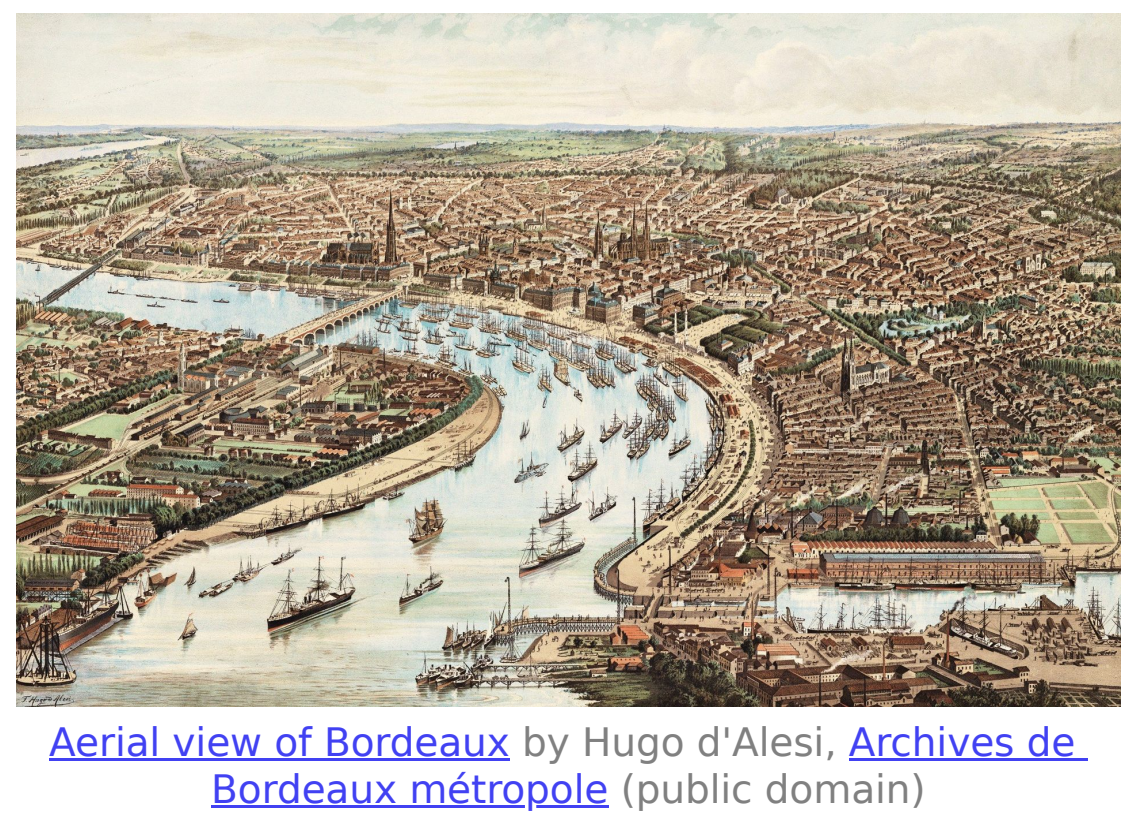

It's also an area that was already making wines, even prior to 1152. But the key thing is that those wines very early on were being made for an export market, which meant that they had to survive the rigors of a sea voyage. They also had to cater to the taste of a foreign audience - primarily an English audience. Secondly, an Irish audience because Ireland, the kingdom of Ireland, belonged to the kings of England, going back to the 11 th century. Moreover, when those wines made it to England, they were then often re-exported across the channel in the North Sea, to the Netherlands, and to ports throughout, what is today, northern Germany and Scandinavia. 


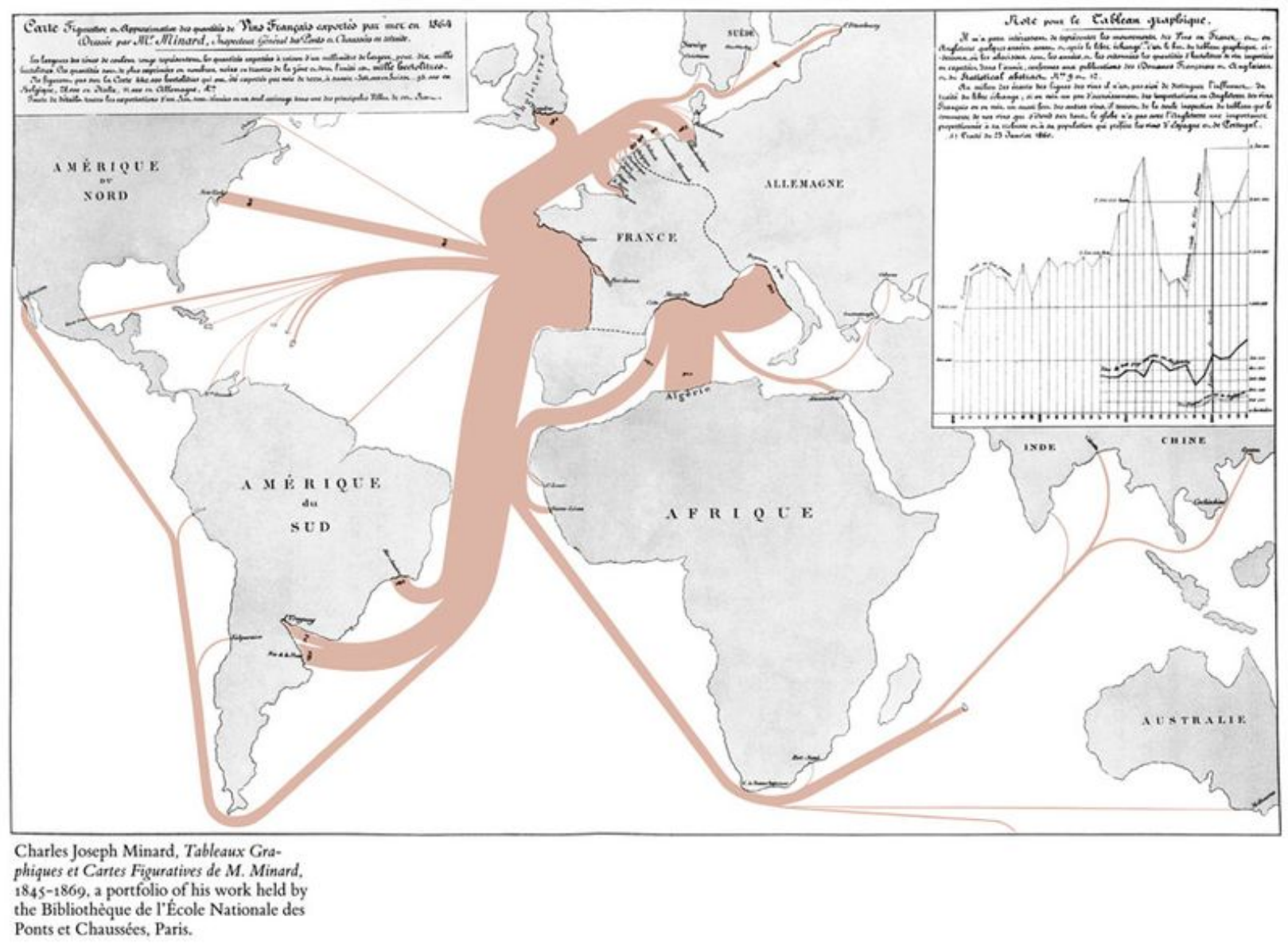

Carte figurative et approximative des quantités de vin français exportés par mer en 1864 by Charles Minard (public domain). Map of French wine exports by sea for 1864.

All those different markets had slightly different desires for what they wanted in their Bordeaux wine. Some of them wanted more red. Some of them wanted more white.

Again the English were the primary market for Bordeaux wine. The local market wasn't nearly as strong as the export market. The export to England began to change, in terms of the quality of the wine, in the 1660s.

\section{A History of War and Wine}

England lost possession of Aquitaine in 1453, when they lost the Hundred Years' War. However, they continued to drink wines from the Bordeaux region. Yet, in the 1660s and 70s, what happened was a sequence of both tariff wars between England and France, as well as actual wars. The French government, in an attempt to protect its own cloth manufacturing market, put a high tariff on English cloth, which was England's greatest export to France. The English subsequently retaliated in 1678 with 
their first, among many embargoes on French wine. But then those were followed by high tariffs on French wine.

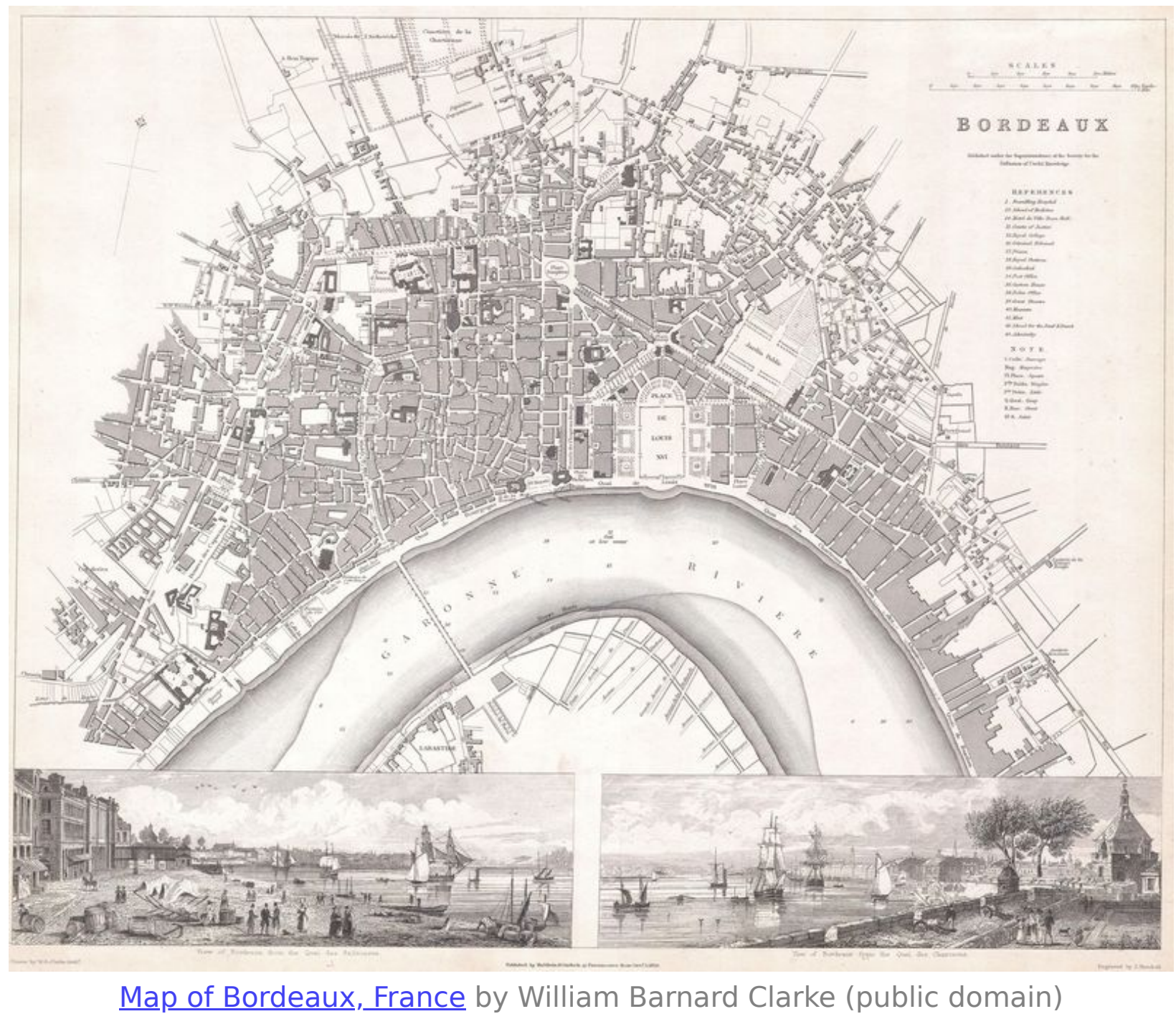

In order to get their wine to the English market and because of the very high flat tax, producers in Bordeaux, regardless of the quality of the wine, had to make a wine that was worth the while of consumers to pay the extra high tax on.

In other words, if you're buying a wine, and half of the cost of the wine, or even more, is in tax, you would rather not purchase it. You'd rather purchase a wine where the tax was a smaller percentage of the overall cost of the wine. So, the incentive is to improve the quality of the wine, which is precisely what happened in Bordeaux. As a result, the wine became darker and more concentrated. Traditional Bordeaux wine was pink in color - we'd call it a rosé or a dark rosé. It became dark in color. 


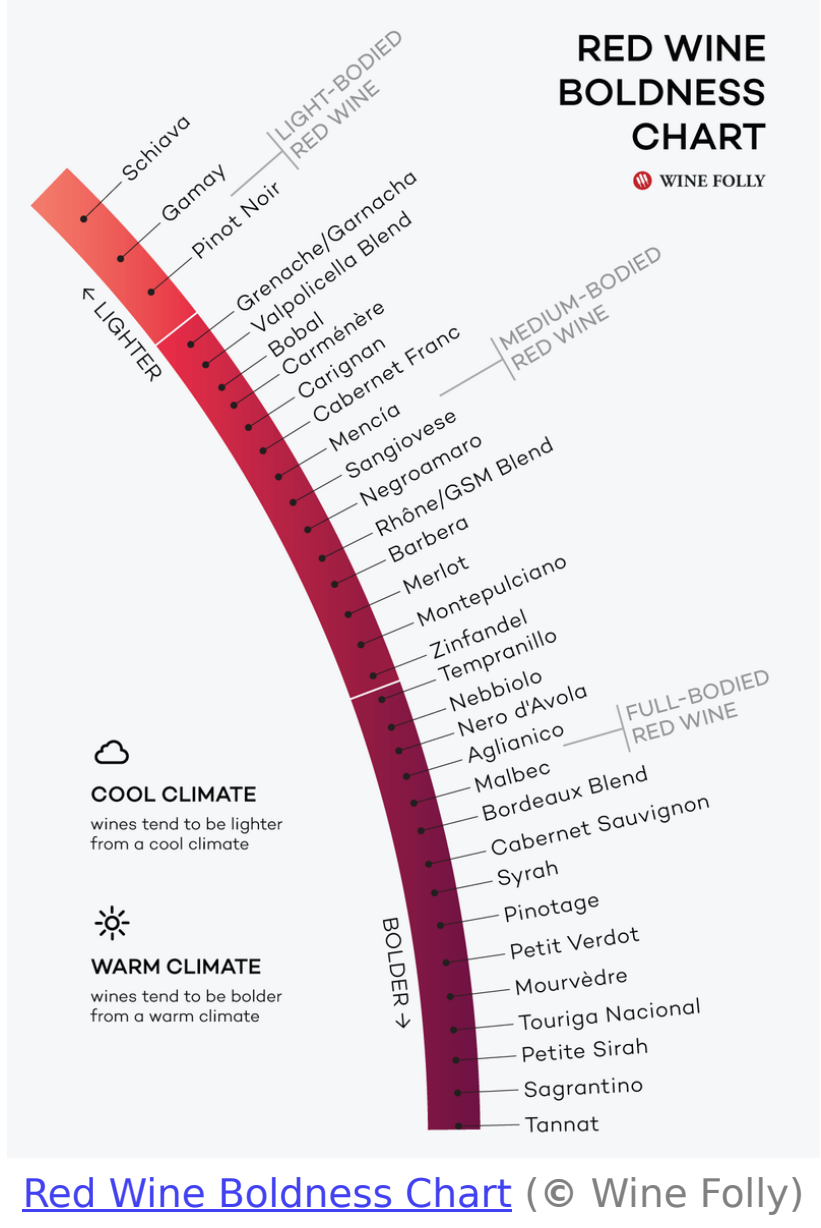

Interestingly, we can see parts of this history in cellar books - such as that of of King_ $\underline{\text { Charles II (1660) and the winner of the Château Haut-Brion Historical Challenge }}$ (1521).

All of the details are in Latin, but they have to do with his wine purchases, including a wine called Haut-Brion, which became the model for high quality Bordeaux wine. And it remains one of the most famous of all Bordeaux wines today.

With greater profits coming in to the French producers, they began to invest more in the vineyard itself to make better wine, which would then fetch ever more money on the English market. And one aspect of creating that better wine was to cull many varieties of grapes that had been grown in Bordeaux.

In the Middle Ages, there were dozens and dozens of types of grapes in the Bordeaux region. Over time, as Bordeaux moved toward quality to reach that English market, they winnowed the number down to five grapes. Again, we see a drive toward quality, which is reducing the number of types of grapes that are grown. Of these five, it was 
predominantly Merlot, which is the most commonly planted, and Cabernet Sauvignon. That combination really came into play at the end of the 18th century.

\section{Visit the web version of this article to view interactive content.}

\section{The Geography of Wine + Flavors/Taste}

\section{Visit the web version of this article to view interactive content.}

On the left bank of the Gironde River, which becomes the Garonne River, everything to the left, or the west, focuses more on Cabernet

Sauvignon, with a minority of Merlot. The exception is in the white wine growing regions. For example, down here, where they make sweet white wine, the most famous of which is Sauternes.

To the right of the river, or east of the river - that's Merlot country, where Merlot is the dominant grape, and Cabernet Franc is the minority grape and Cabernet Sauvignon is used a little bit too.

Why they plant grapes in different places has to do with the soil, the heat, and which grape ripens faster. For example, Cabernet Sauvignon needs more sunshine and heat whereas Merlot needs a little less heat to ripen.

\section{Visit the web version of this article to view interactive content.}

\section{Red Winemaking in Bordeaux Explained by Elicité}

They also have different flavors and bring different things to the wine. In particular, Merlot is often thought to smell like and taste like plums, and the mouth feel kind of jammy, especially if the grapes are very ripe. Although historically in Bordeaux, they haven't grown the Merlot, or let it stay on the vine long enough to get the really jammy flavors you get in a lot of New World Merlots. Instead, sometimes they could have a little more of a strawberry flavor. It also has a high level of acidity.

Cabernet Sauvignon, on the other hand, the dominant grape on the left bank or west side, is often thought to smell and taste like black currants. Yet, people also detect cedar, as well as pencil shavings. 
Cabernet Franc, is a parent to both of those wines. That is, Cabernet Sauvignon is descended from Cabernet Franc and Sauvignon Blanc. It was a random occurrence in nature that produced the Sauvignon Blanc, Cabernet Sauvignon grape. So, a white grape and a red grape produce a red grape Cabernet Sauvignon. But Cabernet Franc is one of these parents, while also a parent of the Merlot grape.

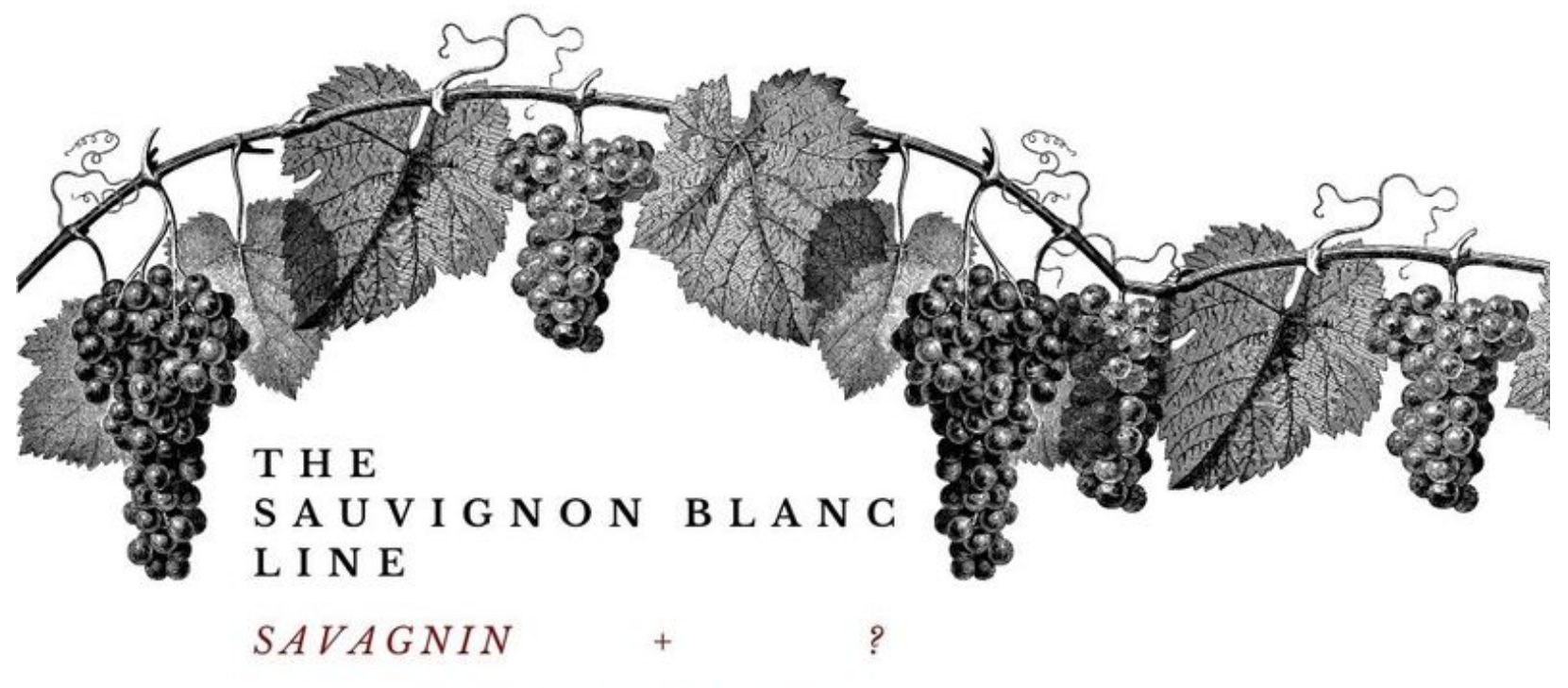

SAUVIGNON BLANC

GROS MANSEN G

C O L O M B A R D

PETIT MANSENG

PETIT MESLIER
C HEN IN B L A N C

GRÜNER VELTLINER

S I L V A N E R

VER D E L H O

C A B ERNET SA U VIG NON

CABERNET FRANC

\section{The Sauvignon Blanc Line by Kelsey Dufresne}

Cabernet Franc is often thought to bring cigar box flavors or tobacco flavors.

Sometimes violets are described and, perhaps less attractively, green pepper or bell pepper - a flavor that I actually find unappealing in wine, but some people, I confess, like it, and that's certainly their business. 


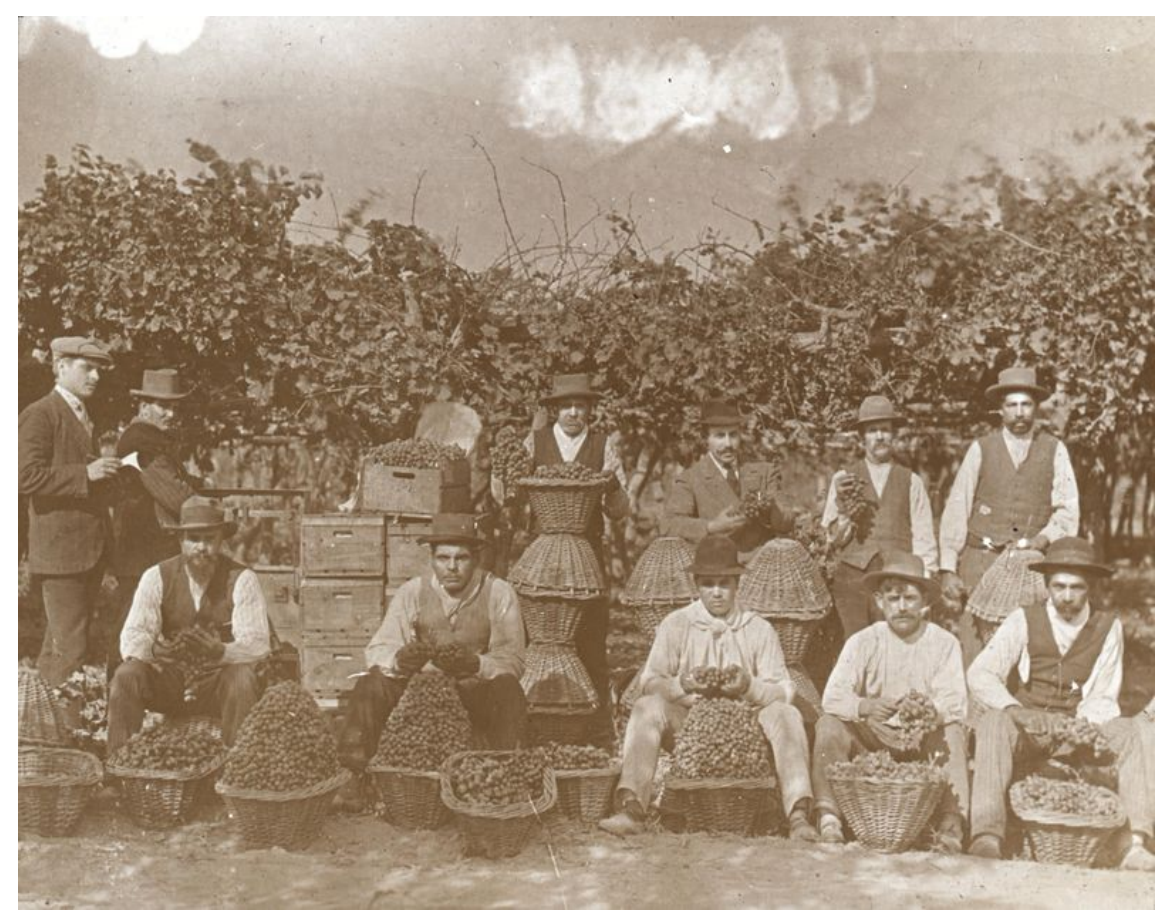

Argentine Grapes from OSU Special Collections \&

Archives (

All Bordeaux wines, again, are made with a combination of grapes. That's done in order to hedge against different types of weather. Burgundy, by contrast, goes with one grape. For red, it's Pinot Noir. And for white, it's Chardonnay. There's an exception to that, but I won't go into that.

In any event, these are all the flavors that people often say they get in these grapes. But critically, the questions I want to ask now are: How do people taste these flavors that I just talked about? What do they do?

\section{How to Taste Wine}

Now, I am switching from historian mode to taster mode to illustrate how one tastes a wine.

We begin when we taste wine by making sure the glass is clean. For this exploration, I have poured, in fact, some Bordeaux wine. This is a 2011, not considered a great year, 10 years old though, for Bordeaux that's pretty good. Often, it takes some time to age.

So, what do we do? 


\section{HOW TO TASTE WINE \\ $S W I R L$ \\ $L O O K$ \\ $S M E L L$ \\ $T A S T E$ \\ Image by Kelsey Dufresne}

1. First of all, I like to swirl it from the start and we hold it up to look at the color because wine comes in first through the eyes before anywhere else. Is the color pretty? If it's not pretty, that actually affects how we taste the wine. But let's say we find it a pretty color. Often, Bordeaux is described as red brick in color. Especially if it's older, it begins to turn slightly brown as it ages.

2. After looking at the wine, having it enter through our eyes, it enters through our nose. We smell it. We try to think of what we get in the wine, what flavors. It helps to think of some of those that I just mentioned before, such as plum, ceder, and tobacco.

3. Then comes the fun part: you taste it. While you're tasting it, try to suck some air in. Let that activate both the wine and your own senses. If you're a professional taster, you're going to want to spit out - because if you did this with 50 wines, and you're trying to rate them all, you would soon find yourself falling down.

But in tasting these wines, what's really going on? 

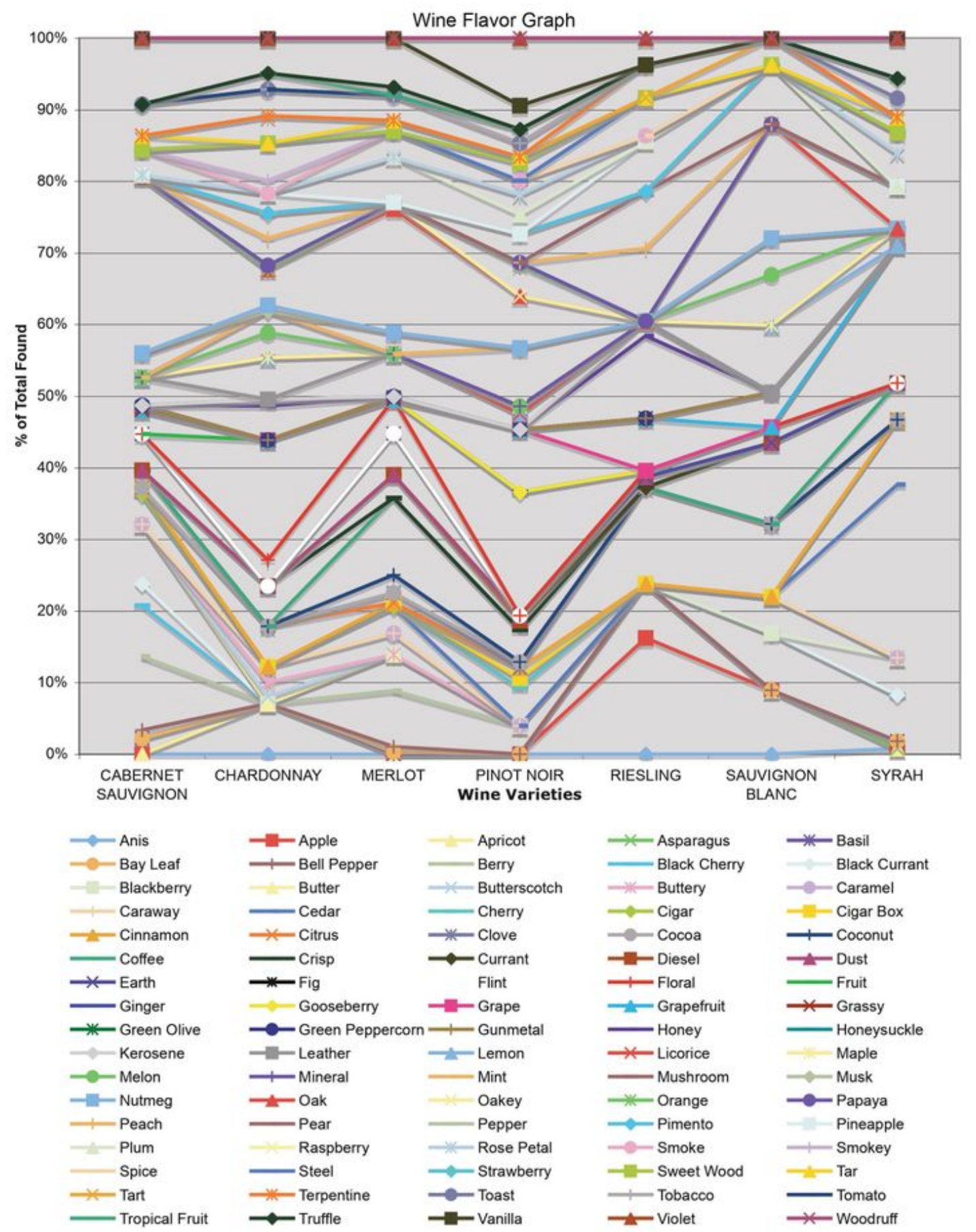

Figure 5 - Graph of Wine Flavors and Varieties

Figure 5: Graph of Wine Flavors and Varieties, from "Visualizing the Flavor of Data" by Corina Schweller ( ( c Corina Schweller) 


\section{Wine on the Brain}

What's going on we actually taste wine? What's happening in the brain? [1]

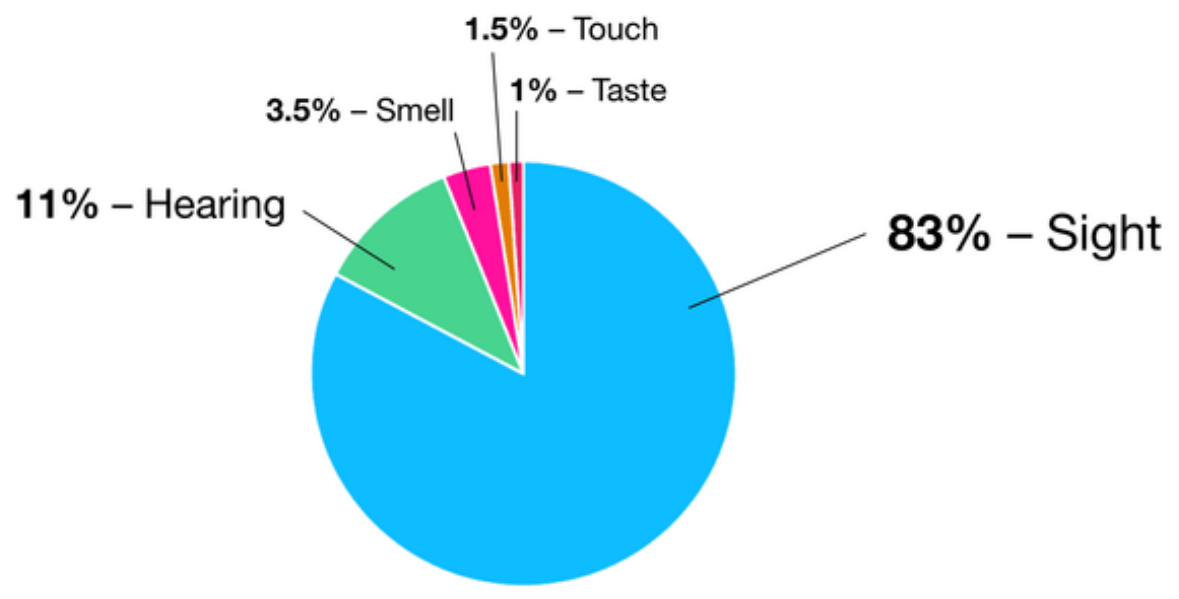

\section{HUMAN PERCEPTION \& COGNITION}

Cite: Dr. L.D. Rosenblum, Dr. Harold Stolovitch and Dr Erica Keeps

\section{How Finding Wine Flavors Changes Your Brain For The Better by Dr. L.D. Rosenblum, Dr. Harold Stolovitch and Dr. Erica Keeps}

This is about sensing material history. The complexity of the materials we are smelling and tasting. And the first thing to realize is that we're actually having not one, but two senses of smell. It's often undervalued, just how complex our sensory apparatus is.

The so-called orthonasal olfactory perceptual system is what we usually associate with smelling. The inhaling, the sniffing, often referred to as the fragrance perception. And we have a second pathway, which is the retronasal pathway, associated with flavor perception. And they work similarly yet differently too. 


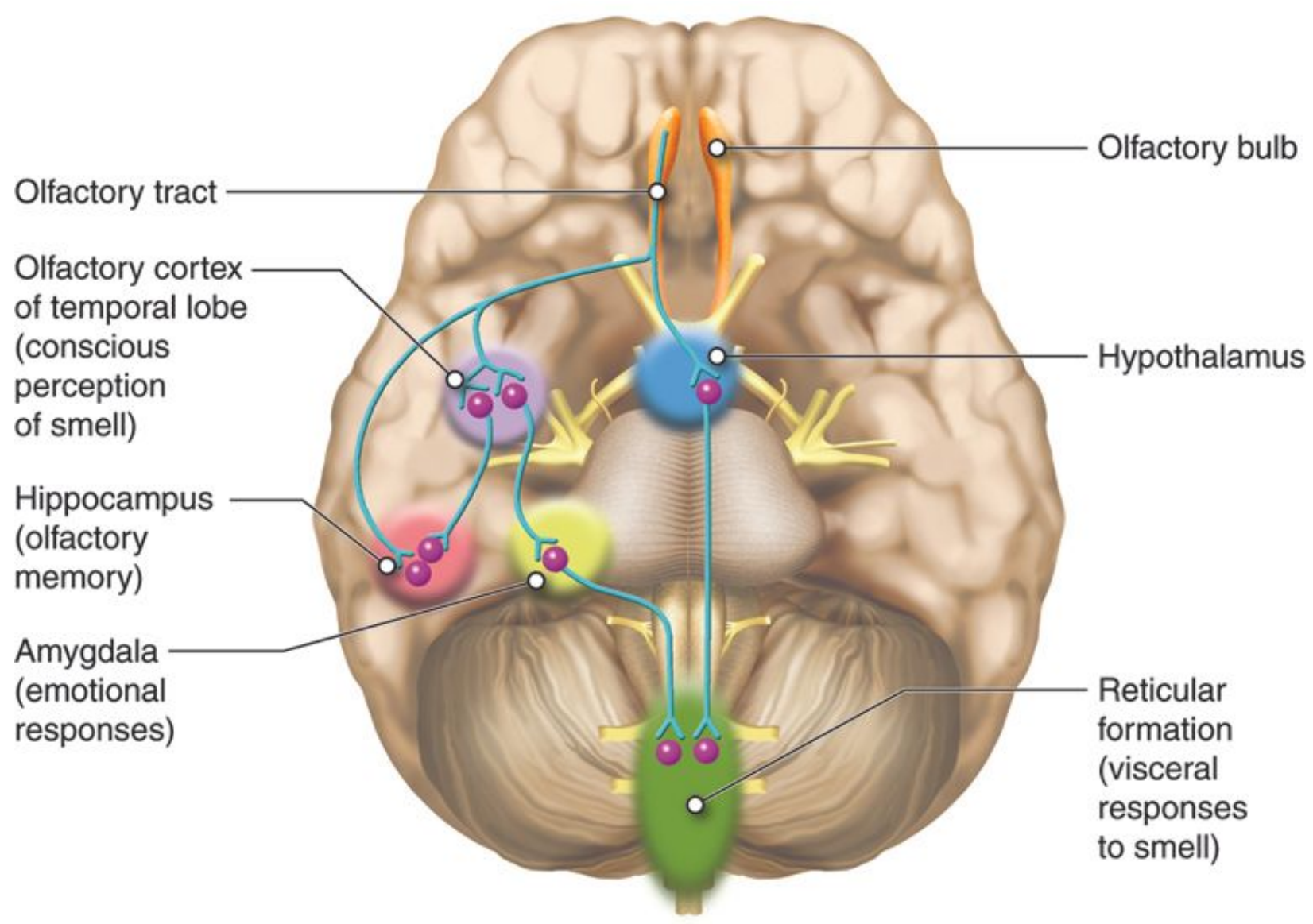

Central Nervous System Regions that Receive Information from the Olfactory Bulb by Cenveo (CC BY 3.0 US)

When you have, for instance, just the sniffing and the inhaling sense - what happens is that you've got very light, airborne, volatile molecules entering up the nose, the nasal cavity, and interacting with the olfactory epithelium, which contains the sensory neurons leading directly into the brain. These sensory neurons have the receptors. They touch and tangle with these molecules. There's a combinatorial interaction going on - meaning you've got one molecule interacting, via different molecular features, with different receptors. One receptor can actually be activated by different molecules with different features. You have a combinatory explosion at your nasal epithelium. That's why you can smell so many different kinds of things. 


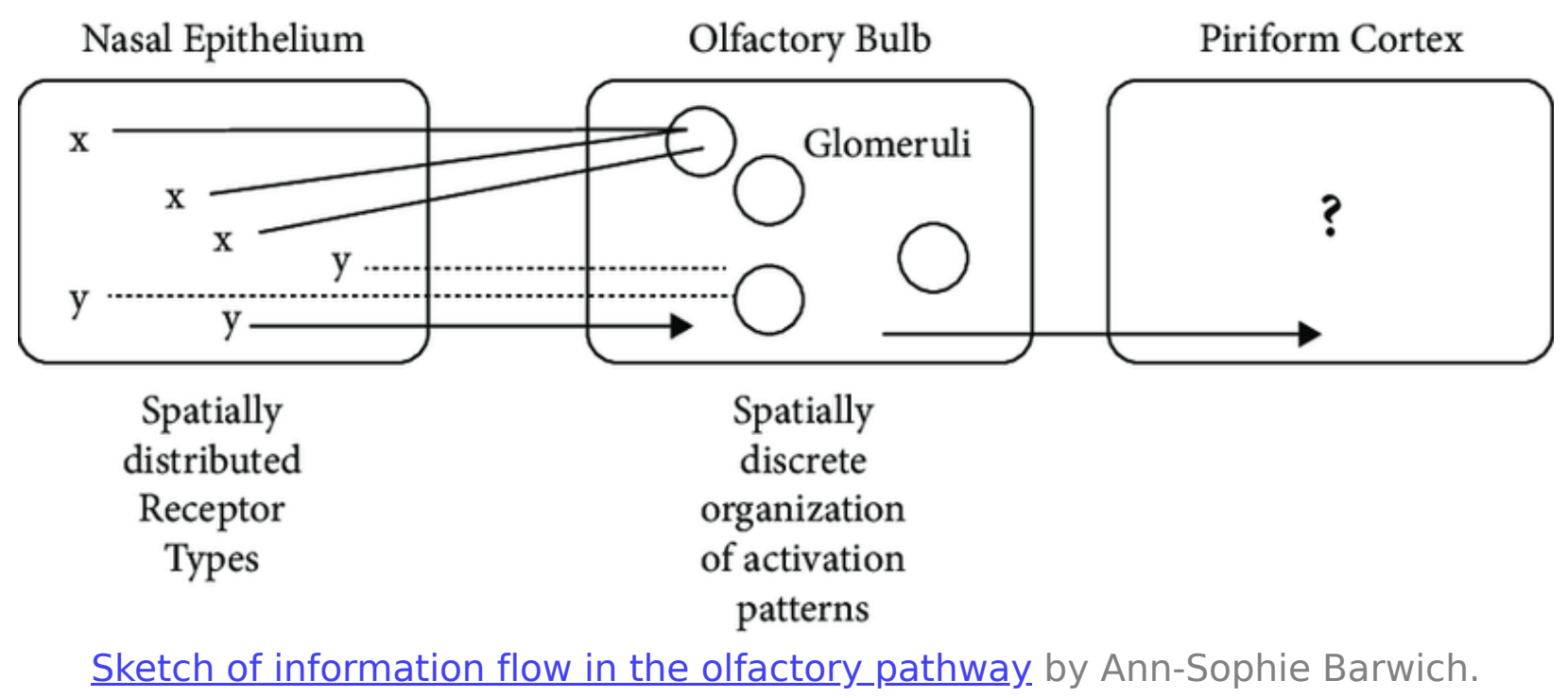

Compared to color, we've got a certain set of things you can discern. With molecules, it's a plethora of everything smells. The reason that you can detect all these different nuances of smells, and categories of smells, is because of the combinatory explosion at the epithelium. And that sends a signal, then, to the first relay station of the brain, the olfactory bulb, at the frontal lobe of your brain, where the signal then is sent further to the olfactory cortex.

This is actually a fairly straightforward pathway. There are two synapses from the ear to the brain. Just by comparison, two synapses won't even get you out of the retina in vision. Thus, this looks like a simple pathway. The devil in your science is in the details.

The reason why they're still many unresolved questions about how we smell is because there's a lot of details going on that may not be so simple.

From the olfactory cortex, you have the signal further interacting with other areas. Such as, for instance, the amygdala, which is involved in effective responses. That's one of the reasons why there's a close, tight interaction between odor perception and judgmental evaluation.

\section{Do we like something, do we dislike something? What kind of response do we have with it? That's the key pathway when we think of sniffing.}

But there's a second sense - and that's when you eat. When you eat, you chew, you've got airborne, volatile molecules, again, released from the food. And they travel back through the back of your throat, up to again, the nasal epithelium, where again, you've got the same process going on. Except for the fact that it doesn't stop there. 


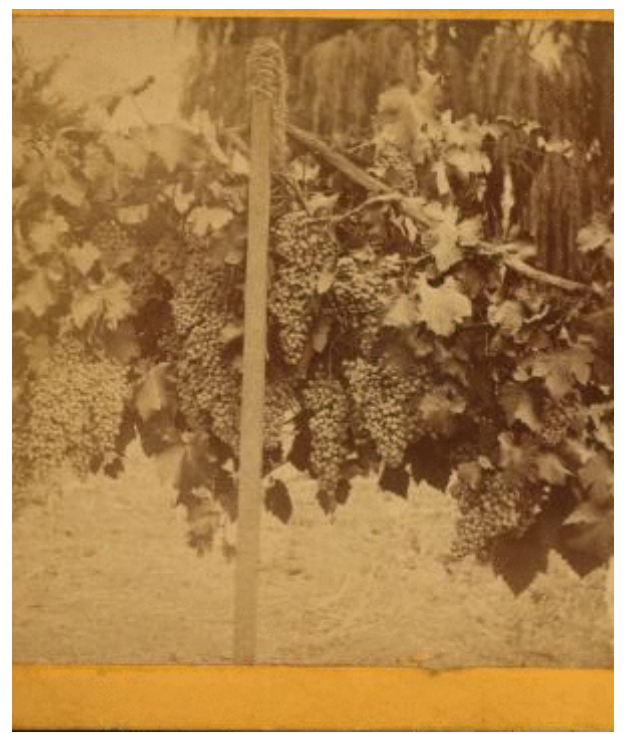

Mission grapes ca. 1875 ( ( New York Public Library).

Created using the

Stereogranimator using the stereograph collections of the New York Public Library.
There is suddenly this multimodal, crossmodal firework, neural firework in your brain. Most of flavor is smell, but you also have the crossmodal interaction with taste, with touch, and with temperature. Their different aspects are often summarized as mouthfeel.

But you also have the visual sense. You see a color that raises certain expectations of what you think you're perceiving.

Also auditory things. Is it crispy? Is it crunchy? Is it kind of slurpy? Your brain basically integrates all these factors together into this sensation we call food and food flavor. $\underline{4}$

Now the question is: To what extent are wine experts able to perceive so many different kinds of things, if we have the same apparatus? 


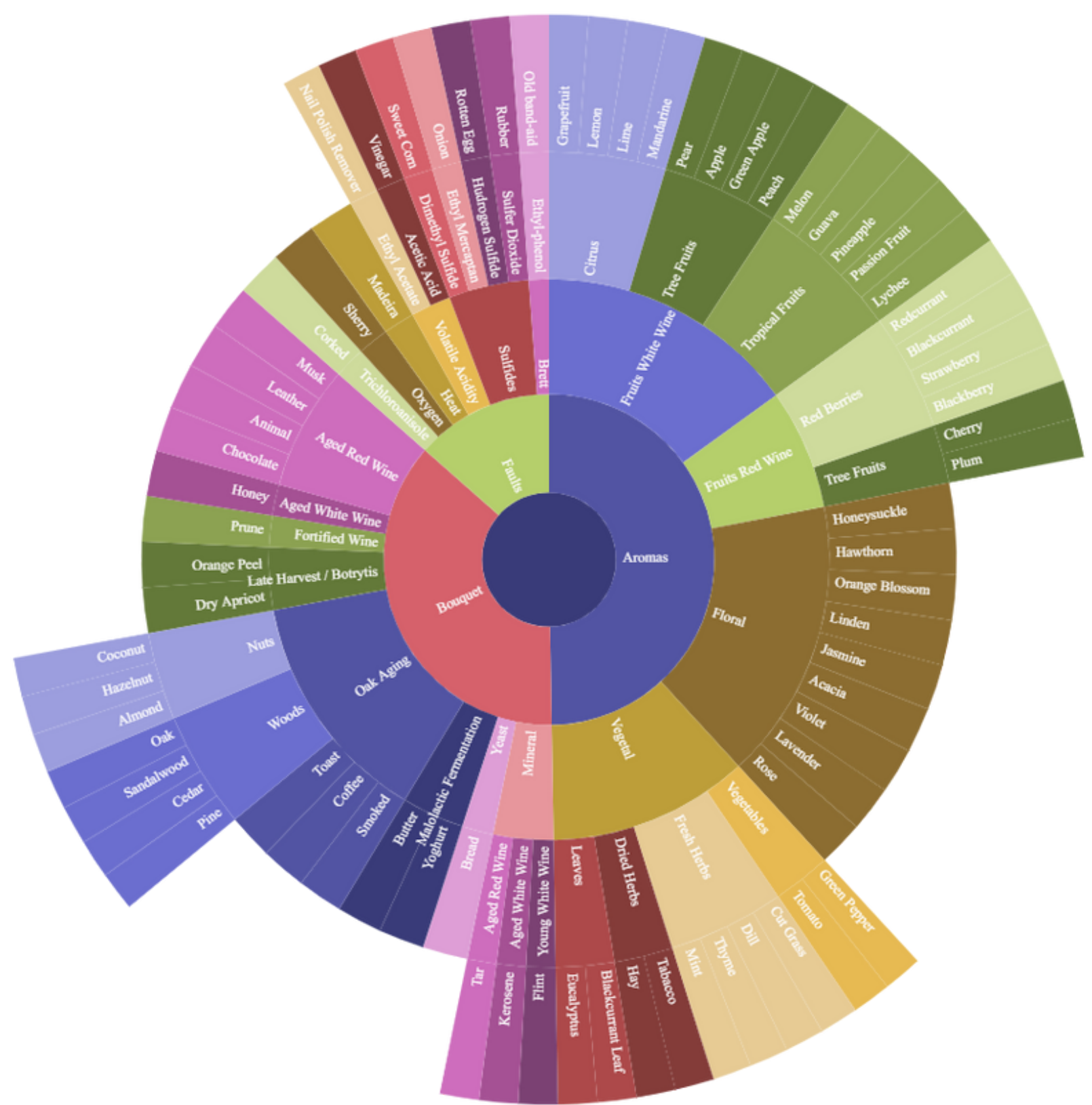

Wine Tasting Wheel by Aculocity, using data from Aromaster ( (

\section{Expert Smellers}

The reason why so many people are so skeptical about sommeliers and wine experts is because they sound slightly fancy. And you can't possibly perceive all that much in wine. It's wine. It's red, it's white. Where do you get all these nuances from? And why can these people say there's pencil shavings in a wine? 


\section{Visit the web version of this article to view interactive content. \\ Interactive Wine Aroma Wheel by Joshua Paul Barnard ( ( ) Joshua Paul Barnard)}

The reason why many people are skeptical about wine expertise, and also other expertise such as a perfumery, cheese experts, coffee tasters, or whisky experts, is that we often think of smell as having this, kind of, stain of subjectivity. This is because you and I, we do perceive things differently sometimes, including certain aromas, or certain smells. Even you can sometimes perceive the same thing differently at different times. We think it's subjective.

> 0:00/1:12:03

$\underline{\mathrm{SCl} P H I}$ Podcast Eppisode 48- Ann-Sophie Barwich. Host Nick Zautra chats with Ann-Sophie Barwich, Visiting Professor in the Cognitive Science Program at Indiana University Bloomington, about growing up studying literature in East Germany, finding her voice as a researcher, and the importance of thinking about the sense of smell as a model for neuroscience and the senses.

\section{The Stain of Subjectivity}

But, I want to convince you to remove the stain of subjectivity, actually, and to rethink it a little bit.

Why do we think smell is subjective? Well, we kind of adopted that idea from the visual system: we have an object, we see it, we describe it, and we have the same terms to describe that object. We consider that objective is when we all find the same words and categories for the same thing.

Turns out, that's very difficult with smell. You have, on the one hand, lots of molecules - there's no fixed number in
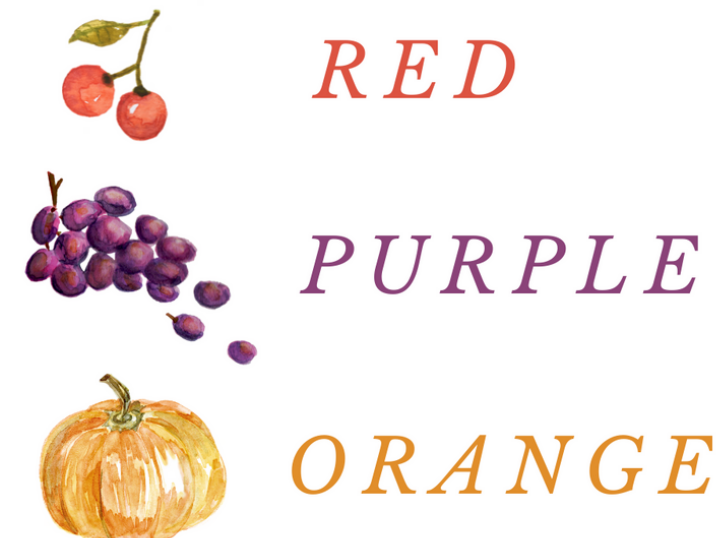

Image by Kelsey Dufresne terms of how many we can perceive.

But some people even suggest that it might be up to one trillion odors that humans can 
discriminate.[2] The number is slightly contested, but I think the official number is shit tons.

There's a lot of stuff we can discern. But how do we describe it? Well, quite often we notice that we use different words for the same molecules, for the same mixtures. The thing is: words are not perceptions. Words are basically what we agree our perceptions are, the categories. The question then is: Why are we having so many different kinds of words for the same things?

Well, one thing to understand is that the variation between us, the variability, is not the same as subjectivity. Subjectivity is something we think is in our heads. It's somehow unaccounted for by objective causes.

It is not that everybody's different, but that there is variation between people. Does the variation have the same causes? Can we actually find common causes of why we are experiencing the same things differently at times?

Turns out we can - because what we often forget when we look at molecules and perceptions is the thing in between. The organism, the biology, and the psychology. There are three examples to hammer that point home:

1. An experiment in 2001 by the psychologist Rachel Herz, gave people two vials.[ㅁ] Identical vials, same liquid, different labels. One was called Parmesan, the other vomit. Well, which one would you smell? Chances are, you'd pick the Parmesan. The thing here is that people are convinced these two bottles actually really smell different. But they have the same mixture, a mix of isovaleric and butyric acids. And you might think, well, that just shows how subjective it is, isn't it? We can fool our sense of smell. No, actually not. It just shows that we can shift our mental imagery. Because it turns out that the olfactory stimulus is often promiscuous.

Butyric acid for instance, both has the smell of Parmesan and vomit, because the same molecules can come from a variety of different sources. The perceptual meaning of a chemical, of a molecule, comes from its context. So there's a semantic ambiguity with many odorus molecules. Your brain measures the context, and it uses crossmodal cues, such as verbal labels or images, to hone in on what that might be.

2. It's not just that there's a promiscuous stimulus when it comes to the chemistry. But there's also genetics involved. The olfactory system is one of the most genetically diverse systems - and these genetic differences can lead to variations in our perception. My favorite example here is corriander or cilantro. At big dinners, you often have one person that expresses that they don't like cilantro and note that it's 
kind of soapy and pungent. $\underline{5}$ That person is not a picky eater or being difficult. People who have a different perception of cilantro as soapy, pungent, not fresh or green, have a mutation near one of the olfactory receptor genes leading them to have a different perception of it. And genetics is a pretty good explanation for it. $\underline{6}$

3. Lastly there is a molecule called androstenone, which is also a pig pheromone - and it does more than just have pigs smell sexy to each other. It also can be smelled by some humans. Those who can smell it either like it or dislike it. To some it's pleasant, to some it's unpleasant. To those to whom it's unpleasant, they even say it smells urinous. Other people who don't like it, say it's smells like body odor. So even though they have a similar negative association and perception of it, they have completely different mental imageries

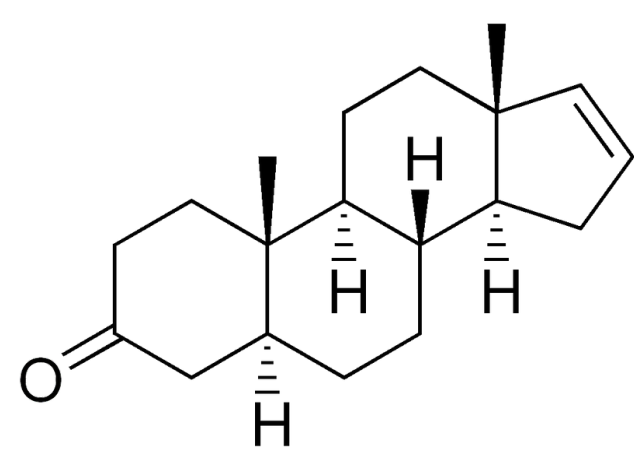

Chemical structure of androstenone by Edgar181 (public domain) of it with differing qualitative descriptors.

Conversely, some people like it because of a detection of a woody smell. Other people say it's very floral.

So you have four completely different ways of perceiving the same thing. And it turns out it's again, back to genetics. So there is a biological foundation for how we perceive, and why we think certain things are so different between us.

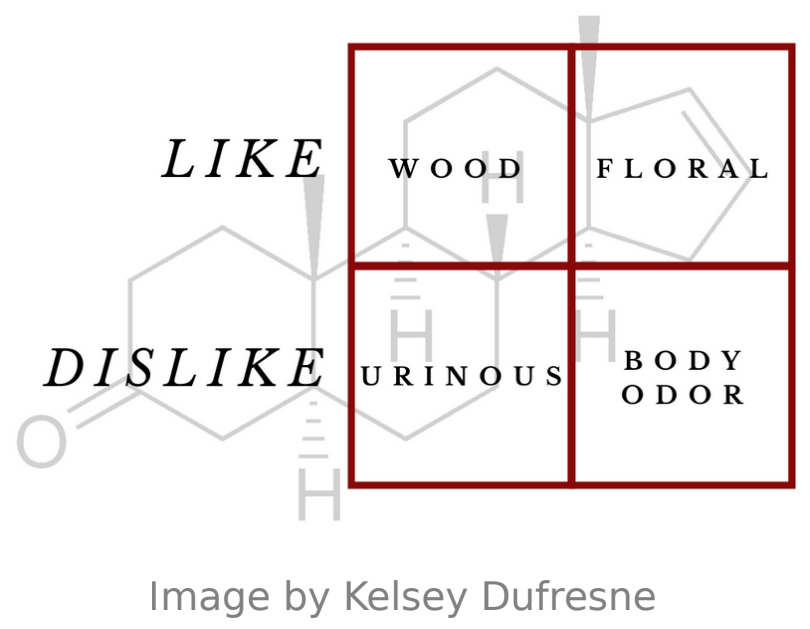
understand both the biological and the cognitive mechanisms, to see what the experts are doing. 


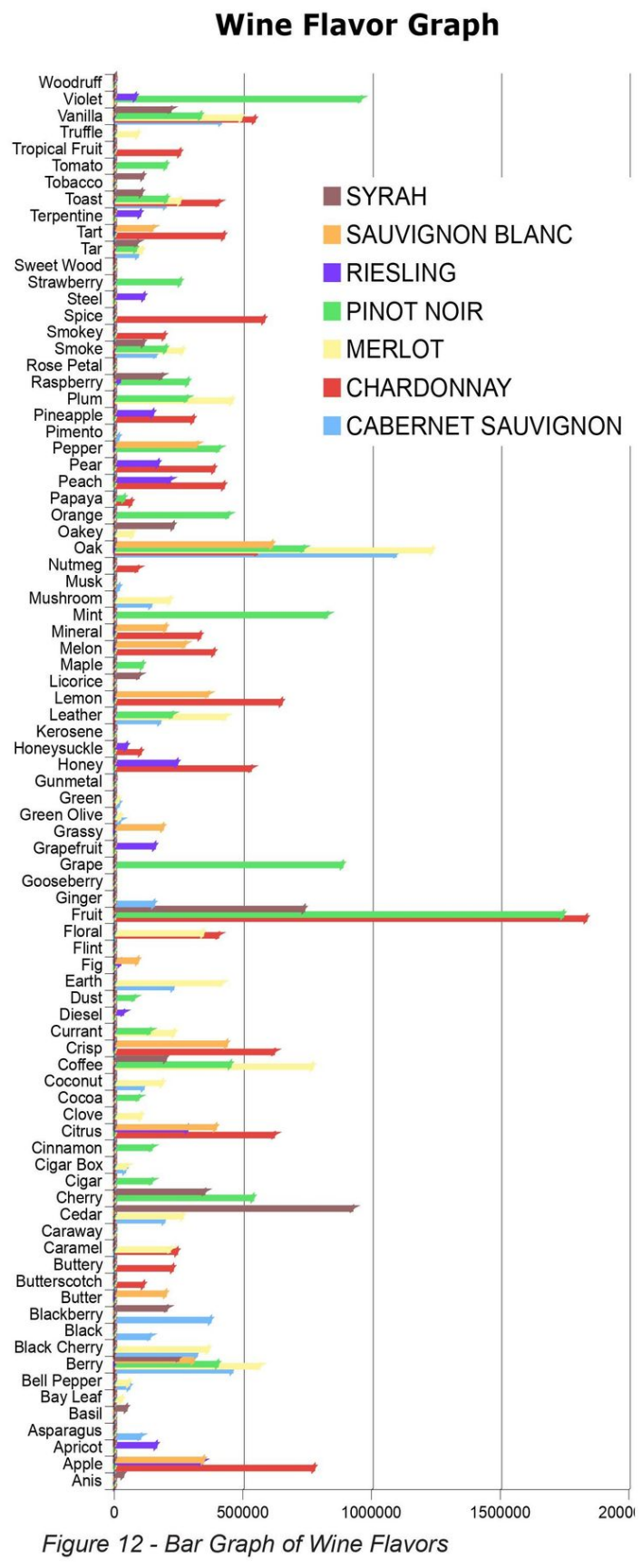

Figure 12: Bar Graph of Wine Flavors, from "Visualizing the Flavor of Data" by Corina Schweller ( ( c Corina Schweller)
Because when you think winetasters can't possibly smell pencil shavings, urine, diesel, or petrol - it is important to remember the key point here: perception is a skill. And what you're detecting is not just simply single molecules. You train yourself. You train your brain to categorize certain things, to pull them out of a complex mixture.

And what wine tasters do, for instance, is that they don't do this just once in a while. They really train themselves, focus on it, over quite a long time. It's like learning a new language. You learn the vocabulary and you get a library of certain wine profiles. Because smelling has a lot to do with memory. Can you hone in? Can you focus on something? And the psychologists call this figureground segregation.[4] Can you pull out certain qualitative features from your memory?

\section{Drinking like a Detective}

It's deductive smelling, much like Sherlock Holmes. So when you look at, for instance, the color of wine, you form a first hypothesis. You make observations. Is there an oily film? Is there more of an orangey film? That already gives you an idea. Then you swallow it, you smell it, you have one or two notes that stick out to you - noting which might be which. And then, because you have this library in your 
head, you can train your brain to find certain notes, or to recognize if something is absent.

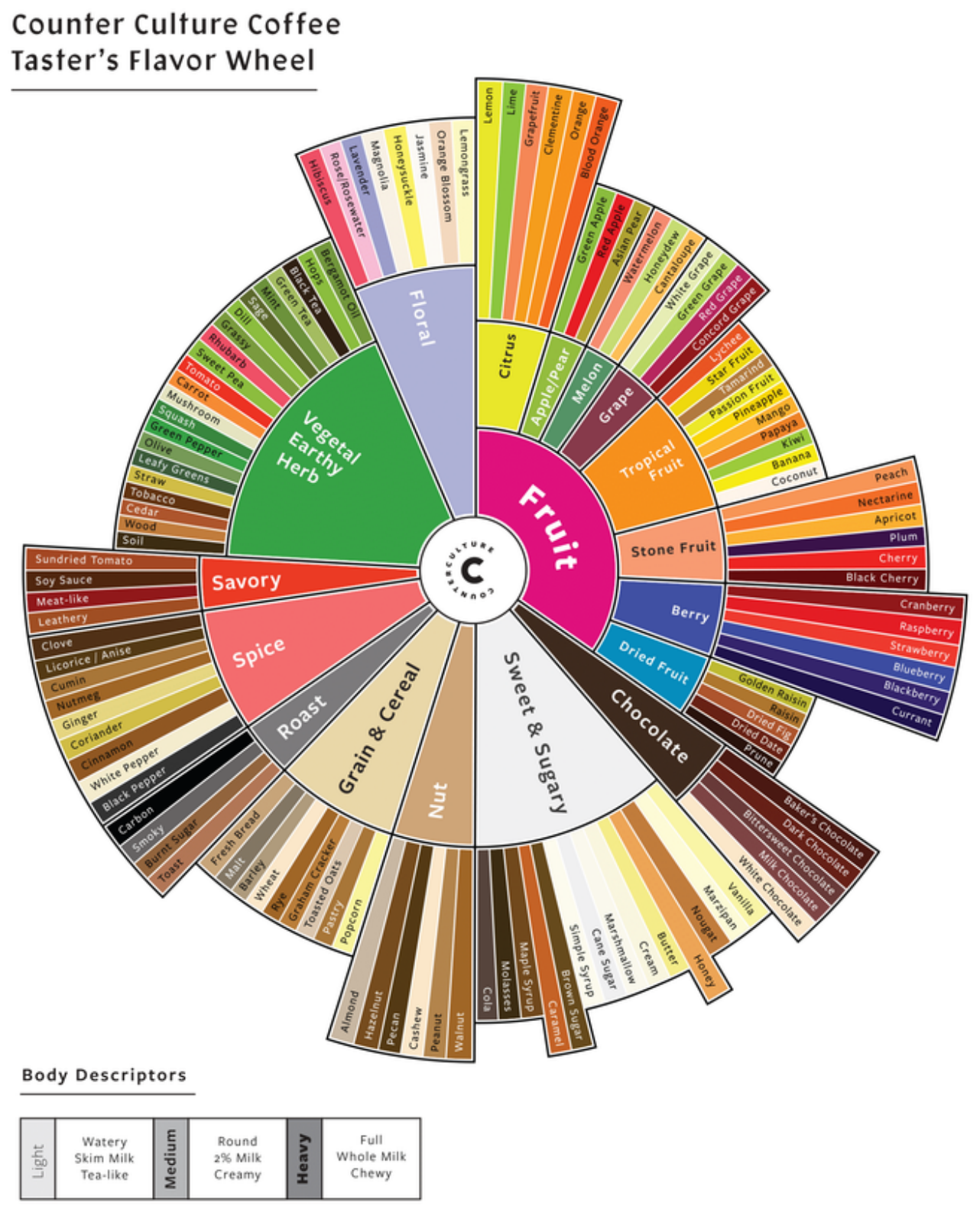

Adjectives \& Intensifiers for Coffee

\begin{tabular}{|c|c|c|c|c|c|c|c|c|c|}
\hline $\begin{array}{c}\text { Crisp } \\
\text { Bright } \\
\text { Vibrant } \\
\text { Tart }\end{array}$ & $\begin{array}{c}\text { Muted } \\
\text { Dull } \\
\text { Mild }\end{array}$ & $\begin{array}{c}\text { Wuld } \\
\text { Shalanced } \\
\text { Sointed }\end{array}$ & $\begin{array}{c}\text { Structured } \\
\text { Balanced }\end{array}$ & $\begin{array}{c}\text { Dense } \\
\text { Deep } \\
\text { Complex }\end{array}$ & $\begin{array}{c}\text { Soft } \\
\text { faint } \\
\text { Delicate }\end{array}$ & $\begin{array}{c}\text { Juicy } \\
\text { Syrupy }\end{array}$ & $\begin{array}{c}\text { Dry } \\
\text { Astringent }\end{array}$ & $\begin{array}{c}\text { Lingering } \\
\text { Coating } \\
\text { Dirty }\end{array}$ & $\begin{array}{c}\text { Quick } \\
\text { Clean }\end{array}$ \\
\hline
\end{tabular}

Taster's Flavor Wheel by Counter Culture ( ( c Counter Culture) 
Sometimes, you hear Riesling experts say note if they detect oak. The reason is because German Riesling is stored in oak barrels, Australian is not. There you already know which continent the wine might be from.

\section{Brain Power}

What you're having is a highly cognitive procedure. Turns out that these changes, these skills, perception as a skill, is also traceable in the brain. Because when you train yourself, when you train your brain to detect these nuances in wine, it actually alters, not just simply your mind, but also your brain.

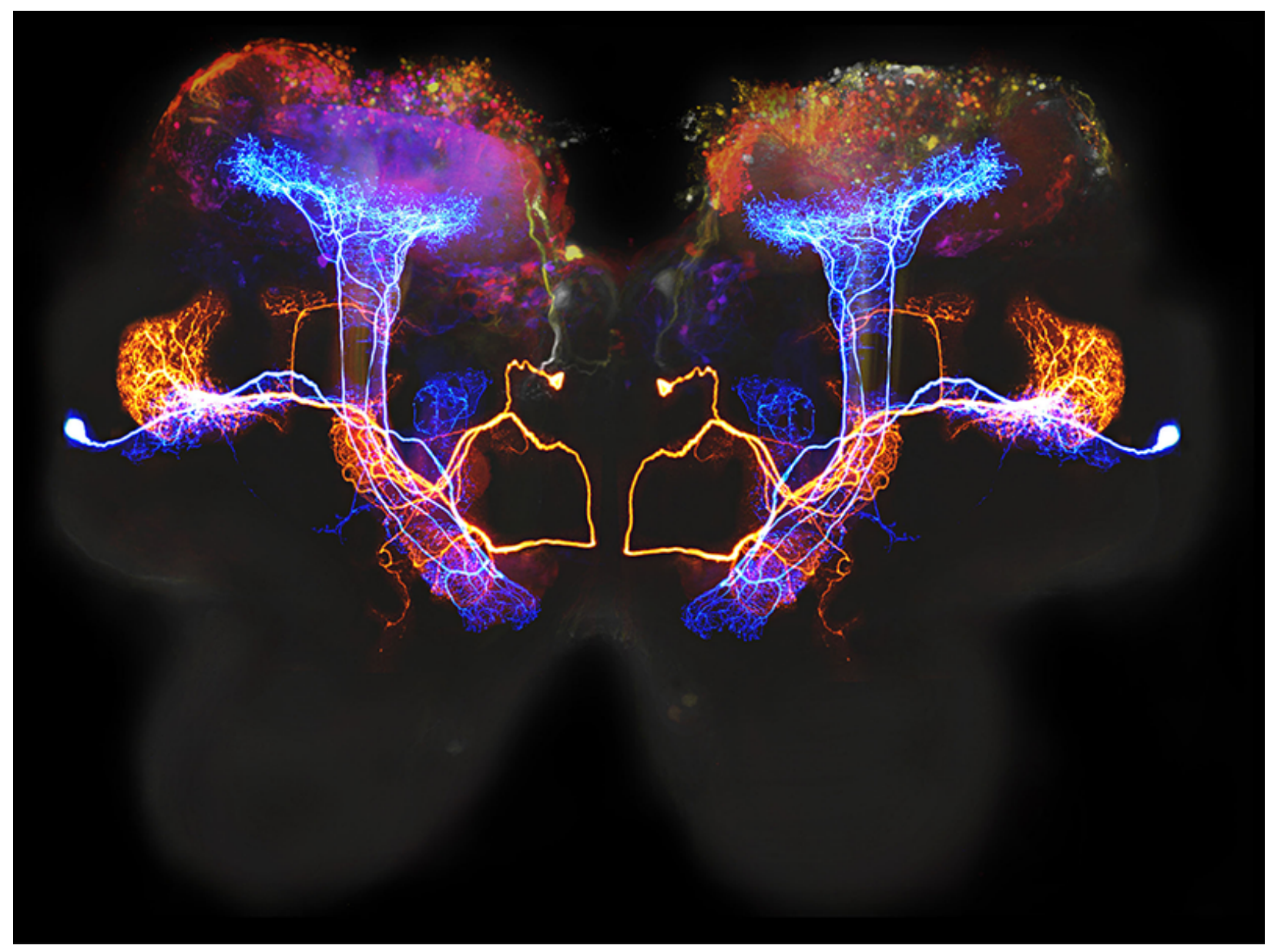

Two pairs of beta lobe neurons (one blue, one orange) in the brain of a locust by National Institute of Child Health and Human Development ( $\underline{\text { NICHD }}$ ( $\underline{\text { CC BY 2.0 }}$ ). These neurons process olfactory information. Toward the top are mushroom bodies, brain areas associated with learning and memory.

It turns out that smell experts have certain areas, as part of the olfactory cortex, that literally get bigger, the gray matter thickens. And the nice thing is, it also can happen 
to you. Because one of the cool things about the olfactory system is that it's the most plastic and flexible system of the brain. [ㅁ]

There were a couple of studies in the last couple of years showing that with intense targeted smell training (meaning 20 minutes of cognitively demanding smell training per day), within six weeks you see changes in the cortical matter.[ㅁ] Which is quite impressive. $\underline{7}$

The brain is kind of like a muscle. And I think, if you're not really the fan of gym procedures and training, wine is a good alternative. And again, it's not subjective, it really has to do with skill.

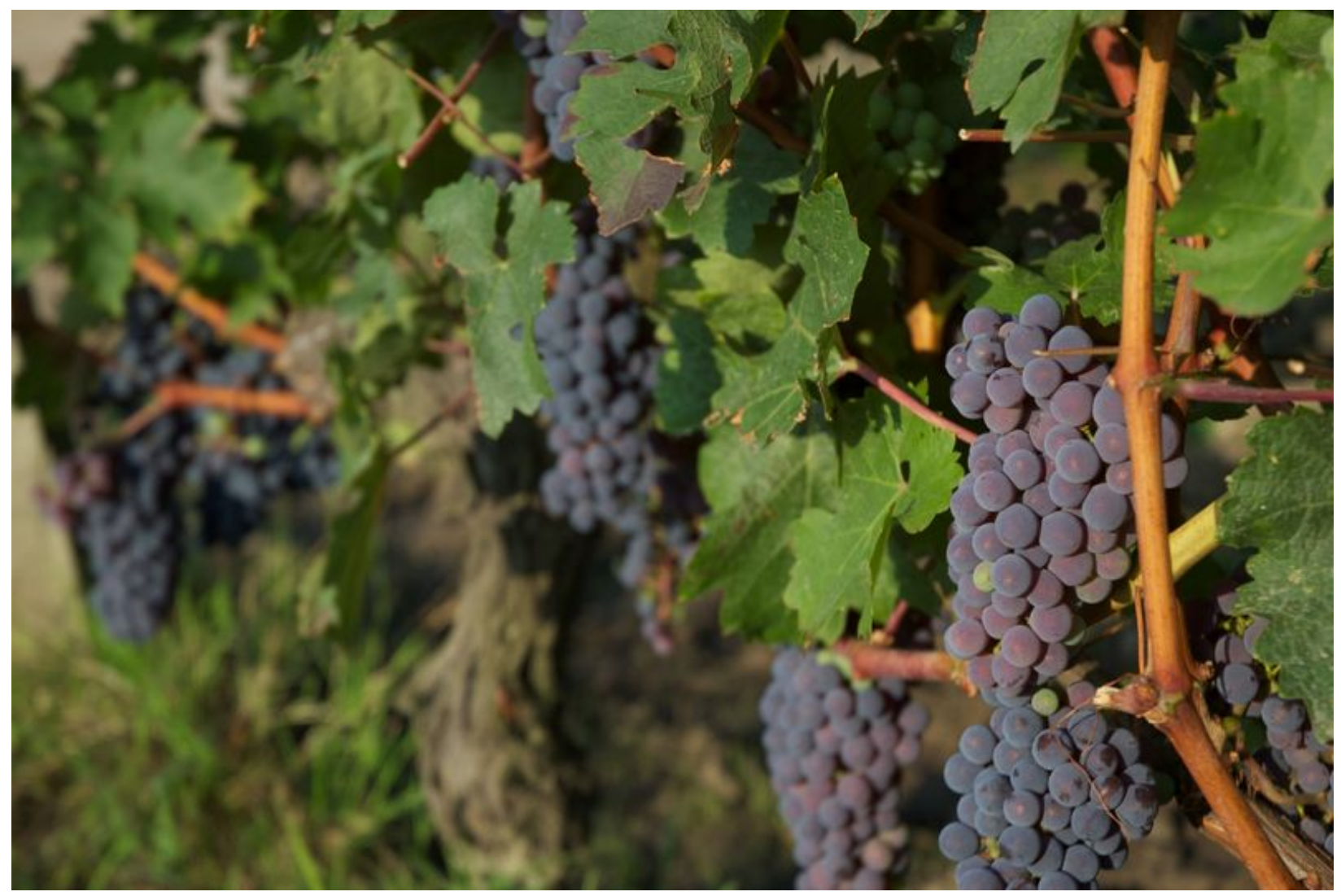

Hotel 'Les Sources de Caudalie' at Chateau Smith Haut Lafitte, Bordeaux by Paul Jackson (CC BY 3.0) 


\section{A DIALOGUE ON WINE}

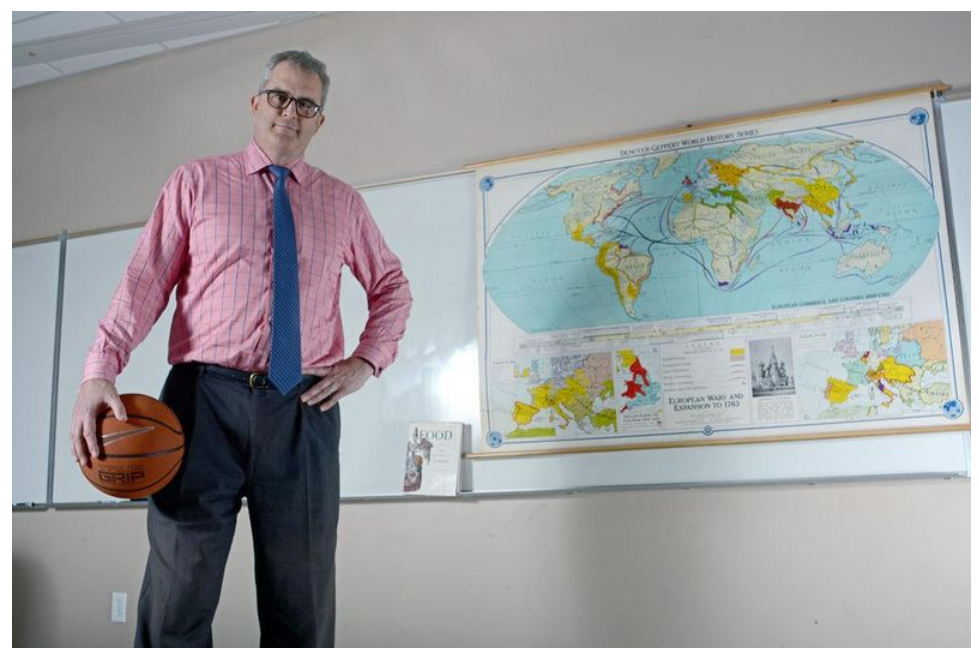

Chad Ludington photographed by Caide Wooten ( (c) Technician)
Chad's Commentary on the Cognitive Practice of Tasting Wine

We can actually quantify many things we do. We know that certain athletes are better than others at whatever it is that they're trying to do. Some people are faster at sprinting 100 meters. Some people can throw a javelin farther, hit a baseball farther, or whatever it might be. Is it the tasters who provide what we can measure?

Or can we actually measure the wines themselves?

I have this theory, based upon spending a lot of time with people who enjoy wine and drink wine, is that over time we begin to congregate around a certain number of wines. We agree that there are certain wines that are objectively better than others. But I realize and write about the fact that there's a lot of subjectivity in that our culture tells us so much about wines. And it's hard that we can't drink wine outside of a cultural, or even economic context. Is there any way to objectively grade wines themselves?

I'd like to think that there's something objective to it. It's not simply acculturation. And it's not just the tasters who become better, there's something in the wine that has quality notes. That is, between acidity, and fruit, complexity, and tannin, that is the grip in your mouth, that give this wine a certain balance. And therefore, people tend to gravitate, not towards the exact same wine, they can never agree on specifics, but towards the same group of wines as being the best wine. 


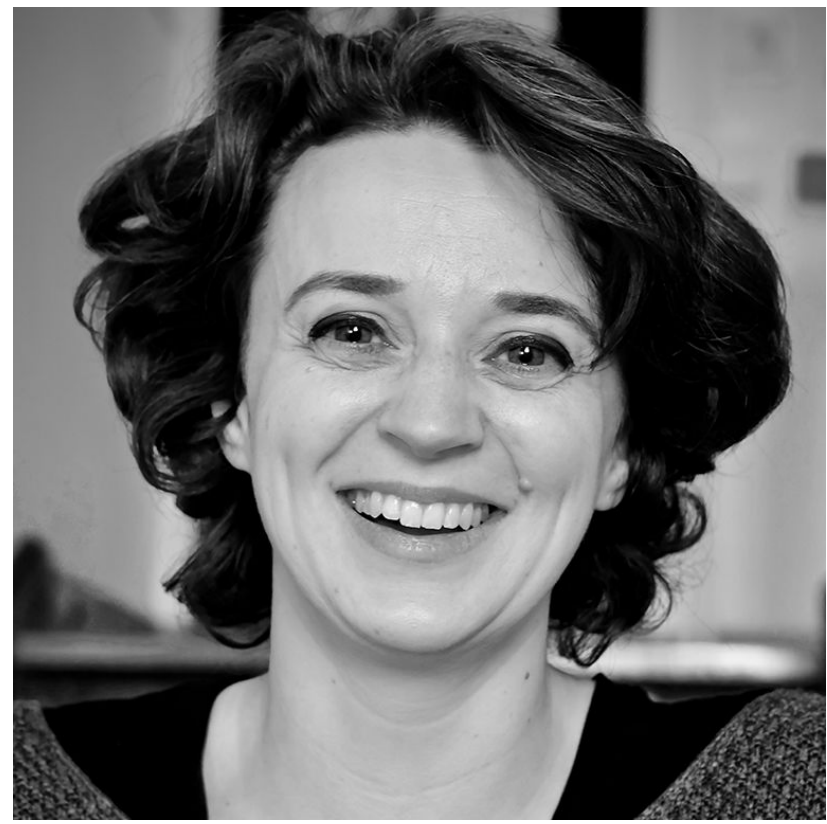

Ann-Sophie Barwich. Photograph from Indiana University Bloomington.

\section{Ann-Sophie's Commentary on Training our Minds with Wine}

The nice thing is when we talk about the objectivity of wine, it's both the sensory system allowing you to do certain discriminations, evaluations. And this is why it's important to look for the underlying principles that allow us to do that.

The other thing is also the material reality. There's two ways to speak about objectivity. One thing is: What we are able to do? The other thing is: What is there in terms of materials? And there is a certain objectivity when it comes to the quality and the composition of a

wine.

And this is what you see in the food industry. There are people in the research and development departments that make a certain objective basis for food products, including wine. And when it comes to wine, there are certain qualities that make a good wine, especially a good wine, as a certain kind of wine. Let's say, this is kind of, the good profile for good Merlot. And this is partly in the sense that you could say there's a differentiation between being able to detect certain things as qualitatively higher-- Like, there's a nice balance, for instance. There's certain notes signifying a wine as being a good representative example of, let's say, good Merlot.

Versus, you might not like Merlot, but liking and the objectivity of tasting, as evaluating the quality of the wine, is not the same. I might say, Oh, this is a wonderful Riesling. It has all these kind of features, it's just that I don't really like Riesling. So you can differentiate between liking, and the quality of wine as being of a particular standard.

There is both the ability to taste objectively, as well as having a certain quality of the things you're judging.

Go stretch your wine muscles in your brains. I'm going to go do that right now. 


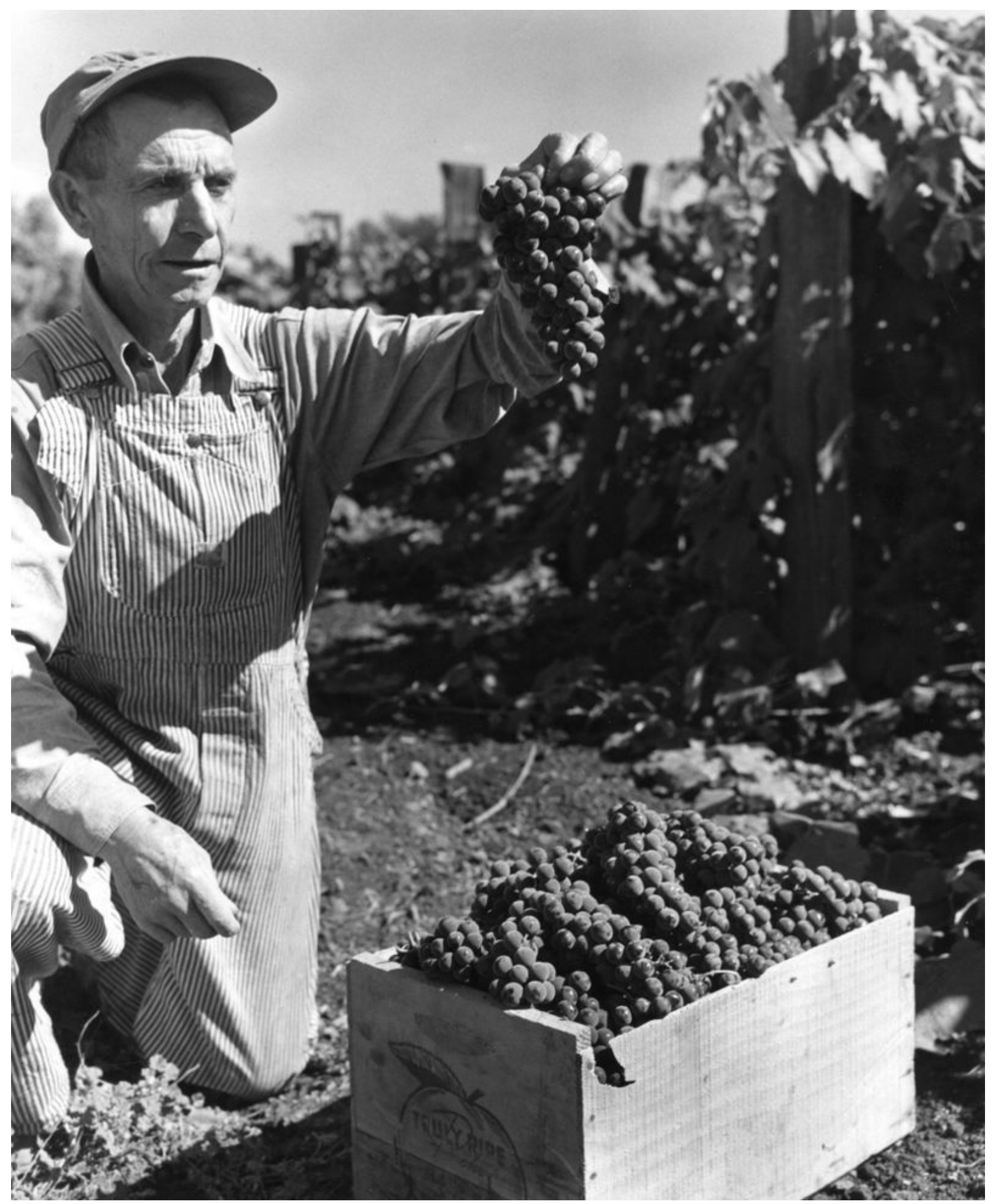

Frank A. Johnson admires a bunch of his well-grown grapes (Concord variety.), Salem, Oregon, circa 1935 from OSU Special Collections \& Archives (Commons) 


\section{Footnotes}

1. For a glossary of wine terminology, please refer to Stanford's Glossary. $\doteq$

2. Conversely, to learn about North Carolina wine practices, please read "The North Carolina Winegrape Grower's Guide" by Barclay Poling and Sara Spayd from NC State University Extension (2015) or the Southern Region Small Fruit Consortium's "Crops - Bunch Grapes."

3. Data about the Merlot and Cabernet Sauvignon grapes are maintained in the Vitis International Variety Catalogue (VIVC), which provides "documentation of the grape genetic resources" and an "information source for breeders, researchers, wine growers, etc." $\doteq$

4.

"According to Yale neuroscientist Gordon Shepherd, the flavor of wine 'engages more of our brain than any other human behavior.' The apparently simple act of sipping Merlot involves a complex interplay of air and liquid controlled by coordinated movements of the the tongue, jaw, diaphragm and throat."

For more information on how our brains shape our wine tasting, please read Mark Schatzker's “The Taste Of Wine Isn't All In Your Head, But Your Brain Sure Helps" from NPR. $\doteq$

5. Listen to "Getting To The Root Of The Great Cilantro Divide" by Josh Kurz from NPR to learn more about the impacts of genetics in tasting cilantro, where Kurz explains: "After all this, I'm willing to admit that being a supertaster has nothing to do with hating cilantro. So what could it be? The answer comes to me as I chew cilantro while holding my nose. Without smelling it, I find, it's more like harmless old parsley, but when I release my nose, it's like a bottle of soap." $\triangleq$

6.

Guy Crosby, PhD, CFS writes: "It would seem that super-tasters might have an advantage over everyone else in their ability to taste and enjoy food. Unfortunately, this is not the case. Because they are so sensitive to bitter they tend to be very picky eaters and dislike many foods."

To learn more about the role of genetics with smelling and tasting, please read "Super-Tasters and Non-Tasters: Is it Better to Be Average?" by Guy Crosby, PhD, CFS from Harvard T. H. Chan School of Public Health. $\_$ 
7.

abScent writes about how to train your nose"

"Smell training is actively sniffing the same four scents every day, spending around 20 seconds on each scent and really concentrating on what you're doing.

It's that easy. It's safe, it's recommended by doctors, and anyone can do it.

You will need:

1. Four different fragrances - this is your smell training kit

2. A few minutes every day"

To learn more about smell training and to even practice it yourself, please explore "Welcome to smell training" with abScent. $\subseteq$

\section{Citations}

1. Ann-Sophie Barwich. (2018). "The Cinderella of the Senses: Smell as a Window into Mind and Brain?" 스og.

2. Morrison, J. Human nose can detect 1 trillion odours. Nature (2014).

https://doi.org/10.1038/nature.2014.14904

3. Herz, R. S., \& von Clef, J. (2001). The Influence of Verbal Labeling on the Perception of Odors: Evidence for Olfactory Illusions? Perception, 30(3), 381-391. https://doi.org/10.1068/p3179

4. Lamme, VA. "The neurophysiology of figure-ground segregation in primary visual cortex." Journal of Neuroscience 1 February 1995, 15 (2) 1605-1615; DOI: https://doi.org/10.1523/JNEUROSCI.15-02-01605.1995

5. Royet, J. P., Plailly, J., Saive, A. L., Veyrac, A., \& Delon-Martin, C. (2013). The impact of expertise in olfaction. Frontiers in psychology, 4, 928.

https://doi.org/10.3389/fpsyg.2013.00928

6. Al Aïn S, Poupon D, Hétu S, Mercier N, Steffener J, Frasnelli J. Smell training improves olfactory function and alters brain structure. NeuroImage. $2019 \mathrm{Apr}$ 1;189:45-54. doi: 10.1016/j.neuroimage.2019.01.008. Epub 2019 Jan 7. PMID: 30630079. 